\title{
Saamelaiskielten indefiniittipronominien jäljillä
}

\author{
Markus Juutinen ${ }^{1}$ ja Jukka Mettovaara ${ }^{1[0000-0002-4727-6704]}$ \\ ${ }^{1}$ Oulun yliopisto
}

\begin{abstract}
We provide an overview of indefinite pronouns in Saami languages that have been borrowed or calqued from Finnic, Scandinavian or Russian. We define indefinite pronouns in the traditional way, i.e. encompassing all pronouns not belonging to any other pronoun class. The treatment of Saami indefinite pronouns in earlier literature varies, but generally they haven't received as much attention as other pronouns. From Finnic sources, Saami languages have borrowed e.g. pronouns harva 'few', joku 'some(one)', kaikki 'all', moni 'many' and тии 'other' as well as pronominal elements ikänänsä '-ever', saati 'let alone' and vaikka 'even (if)'. Loans from Scandinavian include e.g. mange 'many', noen någon 'some' and same samma 'same'. Russian loans include pronominal elements $н u$ - 'not (even)' xоmь 'even (if)'. Indefinite pronouns in Saami prove to be rather an open class, and elements with similar meanings have been borrowed time after time. The variation is especially abundant in pronouns of indifference and free choice. Most of the pronouns in our data have been noted as loans before, but there are some unnoticed cases. Especially these warrant further study.
\end{abstract}

Keywords: Saami languages, language contacts, indefinite pronouns.

\section{Johdanto}

Saamelaiskielten pronominien tutkimus on keskittynyt pitkälti persoona-, interrogatiivi- ja demonstratiivipronominien diakronian ja semantiikan selvittämiseen - ymmärrettävistä syistä. Esimerkiksi saamelaiskielten demonstratiivien järjestelmä, jossa on kielestä riippuen neljästä kuuteen jäsentä, on kiinnostava myös typologisesta näkökulmasta (esim. Guttorm 2009; Ylikoski 2020). Persoona- ja interrogatiivipronomininit taas ovat minkä tahansa kielen ydinsanastoa ja edustavat usein historiallisesti pronominien vanhinta kerrostumaa.

Vähemmälle huomiolle niin tutkimuksessa kuin vaikkapa oppijoille tarkoitetuissa kieliopeissa ovat usein jääneet muut pronominit. Tässä artikkelissa luomme yleiskatsauksen saamelaiskielten lainattuihin indefiniittipronomineihin, minkä haluamme toimivan keskustelunavauksena saamelaiskielten indefiniittipronominien tutkimukselle. Artikkelin puitteissa ei kuitenkaan ole mahdollista kuvata yksittäisten saamelaiskielten indefiniittipronominijärjestelmiä eikä yksittäisten indefiniittipronominien käyttöä, vaan ne jäävät tulevien tutkimusten tehtäväksi. 
Artikkelin rakenne on seuraavanlainen": johdannon jälkeen luvussa 2 määrittelemme, mitä tarkoitamme tässä artikkelissa indefiniittipronomineilla, minkälaisia typologisia piirteitä niillä on ja millä tavalla niitä voidaan jaotella. Lisäksi luomme lyhyen silmäyksen indefiniittipronominien käsittelyyn eri saamelaiskielten kielioppikuvauksissa. Luvussa 3 esittelemme saamelaiskielten lainaperäistä indefiniittipronominiaineistoa, josta osaa on käsitelty jo aiemmissa tutkimuksissa. Esitämme aiemmin käsittelemättömiä etymologioita ja rinnastuksia mm. sanoille Ko joku, E kööre ja Ko vee'zz Ki весb. Luvussa 4 teemme yhteenvedon artikkelin annista; aineiston perusteella voi todeta, että merkittävä osa saamelaiskielten indefiniittipronomineista on lainattu ja että itämerensuomesta lainaaminen vaikuttaa olevan jonkin verran yleisempää kuin skandinaavisista kielistä tai venäjästä. Luvussa 5 esitämme vielä mahdollisia aiheita tulevan tutkimuksen varalle.

\section{Taustaa}

Indefiniittisiksi luokiteltavien pronominien ryhmä on sisäisesti heterogeeninen. Tämä johtuu osaksi siitä, että indefiniittipronominien luokka on toiminut kieliopeissa eräänlaisena jäännösluokkana, johon on luokiteltu muihin ryhmiin sopimattomat pronominit (Haspelmath 1997: 11). Esimerkiksi Isossa suomen kieliopissa (ISK) yhdestä suuresta indefiniittipronominien luokasta onkin luovuttu, ja siihen aiemmin kuuluneet jäsenet on jaoteltu tarkemmin lähinnä erilaisiksi kvanttoripronomineiksi (§ 740, 742):

a) indefiniittiset: joku, jokin

b) universaaliset: kaikki, jokainen, kukin

c) kieltohakuiset: (ei) kukaan, mikään

d) samantekevyyden pronominit: kuka, mikä tahansa; kuka, mikä vain

e) summittaisen lukumäärän pronominit: harva, jokunen, muutama, moni, usea

Indefiniittipronominia voi kattoterminä pitää aivan perustellusti ontuvana, sillä osa niistä on pikemmin definiittisiä eikä osa ole varsinaisesti kvanttoreitakaan (Vilkuna 1996: 52). Tällaisina pronominien rajatapauksina voi pitää sanoja sama, mиu, toinen ja eri, joita Haspelmath kutsuu identiteettipronomineiksi tai tarkenteiksi (identity pronouns/determiners) ja jotka hän rajaa pois varsinaisista indefiniittipronomineista. Näiden lisäksi hän jättää indefiniittipronominien ulkopuolelle universaalisia ja summittaisen lukumäärän kvanttoripronomineja vastaavat pronomini-ilmaukset. (ISK $§ 766$; Haspelmath 1997: 11-12.)

Indefiniittipronominien voi odottaa noudattavan sekalaisesta luonteestaan huolimatta pääosin tiettyjä tendenssejä. Indefiniittisyyttä merkitään usein interrogatiivipronominiin liittyvällä taipumattomalla partikkelilla tai partikkeleilla, pronominin reduplikaatiolla tai sitä ei merkitä ollenkaan, vaan pelkkä interrogatiivi voi itsenään saada indefiniittisen merkityksen. Diakronisesti useat indefiniittipronominit ovat kieliopillistuneet verrattain myöhään, minkä vuoksi läheisten sukukieltenkin indefiniittijärjestelmät voivat poiketa paljon toisistaan. (Haspelmath 1997: 235.)

\footnotetext{
${ }^{1}$ Liite https://zenodo.org/record/4596423
} 
Huolimatta indefiniittipronominin kritiikistä määrittelemme ne tässä artikkelissa mahdollisimman laajasti (ks. Sammallahti 2005: 231-243). Tarkastelemme siis syntaktis-semanttisesta näkökulmasta erilaisia kvantifioivia ja indefiniittisiä pronomineja ja pronomineissa esiintyviä aineksia, jotka eivät selvästi kuulu mihinkään toiseen pronominiluokkaan. Pronominiutta tärkeämpänä kriteerinä jonkin kielellisen aineksen mukaan ottamiselle pidämme sitä, että sille voi osoittaa potentiaalisen laina-alkuperän. Tarkastelemme sekä varsinaisia lainoja että käännöslainoja. Emme kuitenkaan lähtökohtaisesti ota kantaa siihen, onko jokin sana levinnyt saamelaiskielten välillä, emmekä määrittele eri pronominien lainautumisen ajallista järjestystä, ellei siitä erikseen mainita. Lainoja on kertynyt saamelaiskieliin eri aikoina, ja kieliryhmän sisäinen lainaaminen on mahdollista ja todennäköistäkin, mutta tällaisten tapausten osoittaminen on usein vaikeaa.

Uralilaisten kielten pronominien joukossa on paljon lainattua. Nimenomaan indefiniittipronomineja tai vastaavia pronominaalisia elementtejä, kuten prefiksejä, partikkeleita ja kliittejä on usein lainattu uralilaisten kielten kontaktikielistä (Alvre 2002; Blokland 2012; Van Alsenoy \& van der Auwera 2015). Tästä syystä kielikontaktien merkkejä onkin sopiva lähteä jäljittämään niistä.

On yhtäältä myös hyvä huomauttaa, että kaikki saamelaiskielten indefiniittipronominit eivät ole lainaa, vaikka suuri osa vaikuttaakin olevan. Esim. kantasaameen palautuva *mūtēmē (> E muvhte 'muutama, joku' Po muhtun id. jne.) voi olla lainattu itämerensuomesta, mutta toisaalta se on voinut muodostua jo ennen kantasaamea (Sammallahti 1998: 250, 255). Samoin kantasaamen *puohken (> Po buot 'kaikki' Ko puk id. jne.) alkuperä on epäselvä (Sammallahti 1998: 233). Osa pronomineista on puolestaan lainattu ennen kantasaamen hajoamista, ja lainanantajakielen määrittely tarkasti on vaikeaa. Vanhoja lainoja on esim. E såemies Po soamis 'eräs, jokin, joku(nen), muutama', joka on lainattu jo esisaameen kantaindoarjasta tai kantaindoeuroopasta (Sammallahti 2001: 402, 408; Holopainen 2018: 165-166; 2019: 235).

Indefiniittipronominien käsittely saamelaiskielten kielioppien kuvauksissa on vaihtelevaa. Annamme seuraavassa esimerkkejä siitä, miten indefiniittipronomineja on käsitelty varsinaisissa kieliopeissa sekä sanakirjojen yhteyteen liitetyissä kielioppiosioissa.

Tarkimmin indefiniittipronomineja on kuvattu pohjois- ja eteläsaamesta. Esimerkiksi pohjoissaamen indefiniittipronomineja ovat käsitelleet aikaansa nähden varsin kattavasti jo Friis (1856: 73-81) ja myöhemmin Nielsen (1926: 134-145). Nykyaikainen, sekin perusteellinen esitys on Sammallahden ja Nickelin (2011: 129-143), jotka jakavat pronominit ensin rakenteen perusteella moniosaisiin ja muihin pronomineihin. Ensin mainittuihin kuuluvat interrogatiivipronominista ja partikkelista, kuten vaikko 'vaikka', feara 'vähän -kin', nu 'niin' ja -ge '-kAAn; -kin' muodostetut pronominit. Seikkaperäisen syntaktis-semanttisen esityksen pohjoissaamen indefiniittipronomineista tarjoaa Sammallahti (2005: 231-235). Eteläsaamen osalta indefiniittisiä pronomineja on kuvannut jonkin verran jo Bergsland (1946: 108-111) ja varsin perusteellisesti myöhemmin Hasselbrink (SüdLpW: 130-137), jonka jako perustuu sekä morfologisiin että syntaktisiin kriteereihin. Maggan \& Maggan (2012: 58-62) sekä Bergslandin (1994: 129-130) eteläsaamen kielioppien indefiniittipronomineja käsittelevä osa on 
suppeampi kuin Hasselbrinkin mutta toisaalta kielenopiskelijoille ja -oppijoille helpommin lähestyttävä. Morottajan ja Olthuisin (tulossa) inarinsaamen koulukielioppi käsittelee indefiniittipronomineina perinteiseen tapaan niitä pronomineja, "jotka eivät kuulu mihinkään muuhun pronominiryhmään”. Indefiniittipronomineja tarkastellaan varmaankin pedagogisista syistä suomen kielen näkökulmasta, mutta osio sisältää kuitenkin runsaasti esimerkkilauseita.

Toisissa kieliopeissa indefiniittipronominien tarkastelu rajoittuu pronominien ja niiden taivutuksen esittelyyn. Vertailevassa piitimen- ja luulajansaamen kieliopissaan Sjaggo (2015: 61-67) käsittelee indefiniittipronomineja tosin lähinnä niiden taivutusta, mutta eri pronominien merkityksiä hän kuvaa vain vähän eikä käyttöesimerkkejä ole juurikaan. Lähinnä taivutusta esittävät kuvaukset ja pronominiluettelot löytyvät lisäksi luulajansaamen (Spiik 1989: 61-64), akkalansaamen (Zaikov 1987: 127-128), kildininsaamen (Kert 1971: 176-177), turjansaamen (Tereškin 2002: 112) ja koltansaamen (Moshnikoff et al. 2009: 57; 2020: 73; Feist 2010: 258-261; 2015: 109-110, 171) indefiniittipronomineista. Wilbur (2014: 140-141) ei käytä piitimensaamen kieliopissaan termiä indefiniittipronomini vaan käsittelee lyhyesti kvanttoreita (quantifiers). Osa kieliopeista taas ei käsittele indefiniittipronomineja tai kvanttoreita lainkaan, näistä esimerkkeinä mainittakoon Halász (1896) piitimensaamesta ja von Gertten (2015) uumajansaamesta.

\section{Saamelaiskielten lainatut indefiniittipronominit ja niissä käytettävät elementit}

Tässä luvussa annamme esimerkkejä saamelaiskieliin lainatuista indefiniittipronomineista sekä partikkeleista, joiden avulla muodostetaan indefiniittipronomineja. Vaikka olemme pyrkineet keräämään mahdollisimman kattavan luettelon lainaelementeistä, lista ei mitä luultavammin ole täydellinen, mikä osaltaan kuvastaa sitä, kuinka paljon indefiniittipronomineja saamelaiskieliin on lainattu.

Mikäli laina-alkuperää on jo aiemmin esitetty, olemme merkinneet viitteen lainalähteen perään. Olemme lähtökohtaisesti käyttäneet saamelaiskielten nykyortografioita, mutta antaneet lähteissä esiintyvän kirjoitusasun, mikäli nykykielten sanakirjoissa ei esiinny kyseistä elementtiä. Luonnollisesti olemme toimineet näin myös akkalansaamen ja turjansaamen kanssa, sillä näille kielille ei ole kehitetty standardisoitua ortografiaa. Olemme kääntäneet annettujen pronominien merkitykset suomeksi lähteiden pohjalta.

\subsection{Itämerensuomalaisista kielistä lainattuja elementtejä}

ainoa ainova (Qvigstad 1893: 83; SSA s.v. ainoa; LpWsch: 157)

Lu ájnno 'ainoa' (LuLpW: 6-7)

Po áidnu 'ainoa', PoJuk áinoa ainua (LpD I: 22; Hansegård 1967: 198)

In áinoo 'ainoa' (InLpW: 114; InSaS: 120)

Ko àĭñàva 'ainoa' (KLpS: 6) 
Itämerensuomen sana on lainattu germaaniselta taholta (ks. myös 3.2, einn ene). Inarinsaamessa esiintyy myös rakenne jyehi áinoo, joka merkitsee 'joka ainoa, jokaikinen'. Tämä rakenne on lainattu suomen rakenteesta joka ainoa:

Sust lâi kääni, mii monnij kollemane jyehi áinoo peeivi.

'Hänellä oli kana, joka muni kultamunan joka ainoa päivä.' (SIKOR)

ehkä, ehkäpä (LpWsch: 37, 1559; SSA s.v. ehkä), vanh. myös 'vaikka, siitä huolimatta että' (NES s.v. ehkä)

E ihkie ihkebe 'tahansa; vaikka', esim. ihkebe gie 'kuka vain', ihkie guktie 'millä tahansa tavalla' (SüdLpW: 748; SydSaO 2007: 137)

Lu ihka ihkapa 'vaikka, huolimatta', esim. ihka(pa) mij 'mitä ikinä', ihka(pa) guhti 'kuka tahansa' (LuLpW: 85; Kintel 2012)

Samaan yhteyteen kuuluvat partikkelit ja konjunktiot

U ïhká 'vaikka', ïhkkabe 'ehkä' (Barruk 2018: 80)

Pi iehkep 'ehkä' (Halász 1896: 22; Wilbur 2020)

Po aHk 'ehkä' (LpWsch: 37)

harva (Hansegård 1967: 153; LpWsch: 1252; SSA s.v. harva)

Po hárvvis 'harva (ei usea)' (LpD II: 307; Nickel \& Sammallahti 2011: 137)

In härvi 'harva (ei usea)' (InLpW: 705; InSaS: 20)

Koltansaamessa hä'rvv (KLpS: 37; KoSaS: 15) ei toimi indefiniittipronominina vaan adjektiivina 'harva, harvinainen', adverbinä 'harvoin' sekä nominina 'isosilmäinen lohiverkko'. Viimeksi mainittu merkitys on myös kildininsaamen sanalla $\chi a \bar{r} v^{a}$ sekä turjansaamen sanalla $\chi \overline{a r} v\left({ }^{a}\right)(\mathrm{KLpS}: 37)$.

\section{ikänänsä, ikään (LpWsch: 1561; Hansegård 1967: 157; SSA s.v. ikä)}

Lu ihkenis 'kuin, niin, tahansa, koskaan, esim. guhti ihkenis 'kuka tahansa' (LuLpW: 85)

Po ihkinassii i ikkkin 'tahansa, hyvänsä', esim. gii ihkinassii 'kuka tahansa' (LpWsch: 1561; LpD II: 370; Nickel \& Sammallahti 2011: 129-130)

In ihenis ihánes 'tahansa, hyvänsä', esim. maid ihenis 'mitä hyvänsä' (InLpW: 887; InSaS: 21)

\section{joku, jonkun}

Koltansaamen puhekielessä esiintyy suomesta lainattuja pronomineja joku 'joku, muutama' sekä joฑku 'joku, jonkun, muutaman'. Näistä molemmat ovat yleisiä jo 1960- ja 1970-luvun arkistonauhoilla, joten kyse ei ole tilapäislainoista. joku voi toimia itsenäisenä subjektina, ja sekä joku että joyku voivat toimia määritteinä.

vââ'žž ko kuâdd joku ǩën-ne ool, de vuõlgat, vuõlgat nacet stä'lmmstääl 'vihaa kun kantaa joku jotakuta kohtaan, niin lähettää, lähettää katsos staalon' (Kotus 9834_1a, 0:08:41) 


\author{
joyku sään säärnai \\ 'muutaman sanan sanoi' (Kotus 17454_1bz, 0:20:04)
}

Vaikka muotojen käyttöalat muistuttavat pitkälti suomen vastaavien muotojen käyttöaloja, on niiden välillä myös eroja, esim. joku voi toimia myös objektin määritteenä. Tästä syystä kyseessä ei ole ainakaan selvästä koodinvaihto, vaan lainaa on mukautettu koltansaamen kielioppiin.

Tä'st võl leei'm võl joku ääi'j.

'täällä olimme vielä jonkin aikaa' (Kotus 12401_1bz, 0:14:35)

Koltansaamen joku joyku -pronominia ei ole aiemmassa tutkimuksessa havaittu, minkä vuoksi sen perusteellinen käsittely vaatisi syvällisempää perehtymistä kuin mihin tämän artikkelin laajuus antaa myöten.

\title{
-kAAn (Juutinen 2016: 57-58)
}

Koltansaamen puhekielessä esiintyy liitepartikkeli -kaan, '-kAAn, edes', joka on lainattu suomen liitepartikkelista $-k A A n$. Sen avulla voidaan muodostaa kieltohakuisia indefiniittipronomineja:

Mutta muuda nåkam nuu'bbnallšem šuurab ää'šs jeä'la šõddâm mõõk-kaan. 'Mutta muita sellaisia isompia sattumuksia ei ole tapahtunut mitään' (Kotus 17448_1c 0:08:52)

I'lleäm müi-kaan kue'lljäu'rr.

'Ei ollut mikään kalajärvi' (Kotus 17461_1d 0:00:57)

\section{kaikki (LpWsch: 2040; Hansegård 1967: 160; SSA s.v. kaikki)}

E gaajhke 'kaikki' (LpWsch: 2040; SüdLpW: 509; SydSaO 2007: 82)

U gájkka 'kaikki, koko' (MalåLpW: 39; Barruk 2018: 57)

Pi gájk gajk 'kaikki, jokainen' (LpWsch: 2040; Wilbur 2020)

Lu gájkka 'kaikki, jokainen' (LpWsch: 2040; LuLpW: 143; Kintel 2012)

Po gait 'kaikki' (LpWsch: 2040; LpD II: 19)

\section{lie(nee) esim. kuka lie(nee)}

Pi litj, esim. mij litj del dat? 'Mikä lie sitten se?' (Wilbur 2009: pit080924.240)

Lu lisj, esim. Ja majt lisj sidjij javllam iv rat diede. 'Ja mitä lie(nee) heille sanonut, en tiedä.' (SIKOR)

Po leš, leaš, leačča esim. In dieđe mii leš dáhpáhuvvan 'En tiedä, mitä lie(nee) tapahtunut.' (SIKOR)

In leš, esim. - - kesittij Avelân maid leš lam sáátuid 'vedätti Ivaloon mitä lienee ollut kyytejä' (Itkonen \& Laitinen 1992: 263)

Ko leežž, esim. Kii leežž leämmaž 'ken lienee ollut' (KLpS: 203)

A -linč, esim. mülinč 'mikä lienee', kïlinč 'kuka lienee' (Zaikov 1987: 127) 
Ki -лйннч, esim. ке-лйннч 'kuka lienee', ми-лйннч 'mikä lienee'; ми-лйннч ляшш туэль альн 'jotain on pöydällä' (Kert 1971: 177; Bartens 1980: 96-97; Antonova 2014: 91, 167)

$\mathrm{T}$-ĺanče, esim. niịit mom ĺanči tomaĺt lìxka 'tyttö jotain siellä tekee', ḱeĺanče puffkāla 'joku ampuu' (Szabó 1967: 132, 146)

Itämerensuomen rakenne kuka lie, mikä lie on käännöslaina venäjän rakenteesta кто-нибудь (Alvre 1982: 51; Laanest 1990: 105). Rakenteen malli on luultavasti lainautunut saameen itämerensuomen kautta; itäisissä saamelaiskielissä rakenteen tavallisuus voi tosin olla venäjän vaikutusta, sillä olla-verbin potentiaalin kieliopillistuminen interrogatiivin yhteyteen indefiniittiseksi elementiksi on edennyt pisimmälle nimenomaan idässä². Akkalan-, kildinin- ja turjansaamessa tähän on voinut osaltaan vaikuttaa myös potentiaalimoduksen taantuminen (Zaikov 1987: 151; Tereškin 2002: 125126; Rießler (tulossa); vrt. Kert 1971: 200-201).

melkeä (LpWsch: 3822; SSA s.v. melkeä) 'paljon, melko suuri, melkoinen määrä, joltinenkin, isonlainen'

Hasselbrink (SüdLpW: 136, 921) esittää, että eteläsaamen mïelgede 'paljon, erittäin' on joko indefiniittipronomini tai adverbi. Koska sanan käyttöä ei juurikaan kuvata eikä sitä tavata muissa lähteissä, on vaikea määritellä, kumpaan luokkaan se kuuluu. Adverbeinä voivat toimia myös seuraavat sanat:

U meälggade 'pitkä (etäisyydestä t. ajasta), etäinen; paljon' (MalåLpW: 93; Barruk 2018: 101)

Po mealgat 'melko, melko paljon, melkoisesti' (LpD II: 711; LpWsch: 3822)

In melgâd 'melko, melkoisesti' (InLpW: 2418; InSaS: 51)

Ko miâlggâd 'melko, melkoisesti' (KLpS: 244; KoSaS: 69)

Piitimensaamen mällgat 'kaukana' (Halász 1896: 70; Wilbur 2020) ja luulajansaamen moelggat 'pitkä (etäisyydestä t. ajasta), kaukana, pitkään' (LuLpW: 564; Kintel 2012) on pikemminkin analysoitava adjektiiveiksi tai adverbeiksi.

moni, monta (Hansegård 1967: 170; SSA s.v. moni; Sammallahti 1998: 255)

E måedtie 'moni, muutama, joku' (LpWsch: 3930; SüdLpW: 936; SydSaO: 197)

U måddie 'moni, usea, paljon' (MalåLpW: 96; Barruk 2018: 106)

Pi mådde 'moni' (LpWsch: 3930; Wilbur 2020)

Lu moadda 'moni' (LpWsch: 3930; LuLpW: 544; Kintel 2012)

Po moadde 'pari, jokunen, moni', (LpD II: 674; LpWsch: 3930) moanat 'monet' (< sm. monet) (LpD II: 677)

In muáddi 'muutama, pari' (InLpW: 2459; InSaS: 55)

Ko muä'dd 'muudan, monias, muutama' (KLpS: 256; KoSaS: 73)

muu (InLpW: 2533, 2535)

\footnotetext{
${ }^{2}$ Kieliopillistuminen on edennyt samalla tavalla myös muissa Venäjällä puhuttavissa ims. kielissä, kuten vatjassa: siäl tšelleb (< tšen + leeb 'ken lie') on 'siellä joku on' (Alvre 1982: 51).
} 
In muh, muide 'muu' (InLpW: 2533, 2535; InSaS: 54)

Ko muиđa тииda, muиk 'muu'

Inarinsaamen pronominilla on vain nämä kaksi muotoa. Ne esiintyvät tavallisimmin kieltolauseissa, ja muh toimii useimmiten subjektina ja muide objektina tai adverbinä. Itkosen mukaan muoto muide olisi lainattu suomen muи-pronominin monikon partitiivista.

muste ij lah muh ko tuše kyehti kuárus kieđâ

'minulla ei ole muuta kuin kaksi tyhjää kättä' (InLpW: 2533)

mut te sij iä uáinám muide ko tom puáris ááhu

'mutta sitten he eivät nähneet muuta kuin sen vanhan akan' (InLpW: 2535).

Koltansaamen puhekielessä esiintyy melko yleisenä suomen partitiivimuodosta muuta lainattu taipumaton pronomini muиđa muuda. Lisäksi olemme löytäneet yhden lauseen, jossa esiintyy pronomini mииk. Se on mиodostettu vartalosta mии lisäämällä koltansaamen monikon nominativvin pääte - $k$ muiden yksitavuisten pronominien tavoin, esim. mii 'mikä' : mõõk 'mitkä', kii 'kuka' : ǩäk 'ketkä'. Tämän perusteella vaikuttaa siltä, että myös inarinsaamen pronominissa muh esiintyvä - $h$ lienee monikon nominatiivin pääte.

Ristte'čč, risttjeä'nn ja muuda- ̌̌i liâ tõ'st pirr.

'Kummisetä, kummitäti ja muitakin on siinä ympärillä.'

(Kotus 9843_1az, 00:31:06)

Tä'st mon jiõm tie'đ muuđa mainsted.

'Tästä minä en osaa muuta kertoa.' (Kotus 3319_1az, 00:44:53)

Lie mâna tu'st, lie, lie-ko mainnâz tai muuk?

'Mahtaako sinulla olla, onko [vielä] kertomuksia tai muita?'

(Kotus 17455_1b 0:18:23)

Tutkimme inarinsaamen $m и$ - ja koltansaamen mииđa $\sim$ mииda -pronomineja myöhemmässä artikkelissamme, joten emme käsittele niitä tässä tämän enempää.

saati (Hansegård 1967: 242; SSA s.v. saati)

E saaht, esim. saaht mij 'mikä vain', saaht gie 'kuka vain' (SüdLpW: 1118; SydSaO: 246)

Po sahte, esim. sahte gii 'kuka tahansa' (LpD II: 387; Sammallahti 2005: 235)

Emme ole löytäneet koltansaamen partikkelin sätt avulla muodostettuja indefiniittipronomineja, mutta se voi toimia ainakin adjektiivien määritteinä, esim.

jiâ tuõsttâm tõn diõtt noorrâd måkkam kuõbbrid sätt. 
'Eivät uskaltaneet sen vuoksi kerätä mitä sieniä tahansa.' (Kotus 12896_1a, $0: 21: 19)$

Samaa alkuperää ovat myös uumajansaamen sahttie 'tavallinen, yleinen, yksinkertainen, ylimääräinen' (MalåLpW: 114; Barruk 2018: 126), luulajansaamen sahte 'tavallinen, yleinen, yksinkertainen; jokapäiväinen', esim. sahte ulmusj 'tavallinen ihminen' (Kintel 2012) ja inarinsaamen säti-, esim. sätisaajeest 'kaikkialla; missä tahansa', sätikandâ 'kuka tahansa poika' (InLpW: 4089). Se voi kuitenkin toimia vain substantiivin määriteosana eikä muodosta varsinaisia indefiniittipronomineja. Myös eteläsaamen sanalla on vastaavaa käyttöä.

\section{tyynni, kaikki tyynni (LpWsch: 8016; SSA s.v. tyynni)}

E dovne 'tasan, jopa, ja, täysin, kaikki' (LpWsch: 8016; SüdLpW: 473; SydSaO: 66)

U gájkka duvnna gájkka dïvdna 'kaikki, jokainen' (Halász 1896: 143; LpWsch: 8016; Barruk 2018: 57)

Pi gájkdivna gájkduvna 'kaikki (yhdessä), kaikki tyynni' (Halász 1896: 143; LpWsch: 8016; Wilbur 2020)

Lu divna 'kaikki' (Kintel 2012)

Po divdna 'kaikki tyynni, tarkkaan, tyystin' (Sammallahti 1993: 67), buotdin 'kokonaan, kaikki tyynni' (LpD I: 259)

In tivnâ, esim. tivnâ-tárkká 'täysin, kokonaan' (InLpW: 5010)

\section{vaikka (LpWsch: 8308; Hansegård 1967: 193; SSA s.v. vaikka)}

Lu vájku 'vaikka', esim. vájku majt dagáv de sjaddá boasstot 'vaikka mitä teen, se menee väärin.' (LpWsch: 8308; LuLpW: 1348; Kintel 2012)

Po vaikko 'vaikka', esim. vaikko gii 'vaikka kuka' (LpD III: 720; LpWsch: 8308; Nickel \& Sammallahti 2011: 129-130)

In veikkâ veik 'vaikka(kin); kuitenkin', esim. veik(kâ) mii 'vaikka mikä' (InLpW: 5471; InSaS: 112)

Ko vaikka 'vaikka' (KLpS: 710), esim. jos kaa'bel ool tuõlmak de sätt että ... vaikka mii šõddâd. 'Jos kaapelin päälle astut, saattaa tapahtua mitä vain' (Kotus 11313_1az, 0:08:30)

Samaan yhteyteen kuulunee myös lausekonjunktiona käytetty Pi vaj gu vijjku 'vaikka' (Wilbur 2020).

vain (InLpW: 5354; SSA s.v. vain)

In váá váin 'vain', esim. kii váá 'kuka vain', kuábbáš váá 'kumpi vain'; puáđus kii váá 'tulkoon kuka vain' (InLpW: 5354)

Ko vain 'vain', esim. kii vain 'kuka vain'

Partikkeli esiintyy koltansaamen puhekielessä. Sen avulla muodostetaan samantekevyyden pronomineja:

See'st le'jje nåkam vue'ǩk̆ leäi te'l saa'min, että sij-han, sij-han mõ'nne 
tanssjed tok, ǩii vain lue'šti si'jjid.

'Heillä koltilla oli silloin sellainen tapa, että he menivät tanssimaan sen luokse, kuka vain laski heidät sisään.' (Kotus 17453_1c, 0:13:04)

Koltansaamea vieraana kielenä puhuvien kielessä esiintyy myös partikkelin pâi 'vain, aina' avulla muodostettuja samantekevyyden pronomineja, esim. kii pâi 'kuka vain'. Nämä pronominit ovat käännöslainoja suomen vastaavista samantekevyyden pronomineista.

Jiõnntee'st vuäitt tuejjeed ǩii pâi maainâst sää'mǩiõol.

'Äänitestin voi tehdä kuka vain puhuu koltansaamea.'

(Yle Sápmi 11.6.2020, viitattu 27.2.2021)

visu 'nuuka, tarkka, säästäväinen' (SSA s.v. visu; Sammallahti 1998: 267)

Lu visut 'perusteellisesti, kokonaan', visu-visut 'jokainen, kaikki (tyynni)' (LuLpW: 1425)

Po visot 'kaikki, kokonaan' (LpD III: 777)

In viisut 'kaikki; kokonaan' (InLpW: 5543)

Vrt. semantiikasta inarinsaamen tivnâ-tárkká 'kaikki tyynni', "tyynni-tarkkaan". Ks. myös 3.3 , весb.

yhtä, yhtään (Hansegård 1967: 259)

PoJuk yht $\bar{a} \sim i h t \bar{a}$ 'yhtä', esim. yhtä mii 'mikä tahansa' (Hansegård 1967: 259), vrt. meänkielen yhtä koska 'milloin tahansa' (Meänkielen sanakirja)

Esimerkkejä Jukkasjärven pohjoissaamen sanan käytöstä3:

Ii yhtä gose gožžan

'Ei kussut mihin tahansa.'

ii dat galgga val mannat čállit yhtä gokte

'Ei pidä mennä kirjoittamaan miten tahansa.'

\section{Kieltohakuiset pronominit}

Inarinsaamessa kielteisiä ilmauksia muodostetaan kielteisen fokuspartikkelin -gin -kin avulla, esim. ij totkin 'ei sekään' sekä ij sungin 'ei hänkään'. Kielessä esiintyy myös pieni joukko sanoja, joissa kielteisyyden ilmaisimena toimii interrogatiivivartaloon lisättävä elementti - $(V) n$. Tällaisia ovat esim. kieltohakuiset indefiniittipronominit mihheen 'mikään' (InLpW: 2442; InSaS: 52) ja kihheen 'kukaan' (InLpW: 1467; InSaS: 30) sekä indefiniittiset adverbit kosten 'missään', koggoon 'missään kohden', kuussân 'minnekään', (InLpW: 1563; InSaS: 33, 35, 38) kuássin 'koskaan' (InLpW:

\footnotetext{
${ }^{3}$ Esimerkit Jukkasjärven pohjoissaamen puhekielen korpuksesta on tätä artikkelia varten luovuttanut käyttöön Olle Kejonen (ks. myös Kejonen 2020).
} 
1582; InSaS: 39), mahten 'mitenkään' (InLpW: 2442; InSaS: 50). Ainakin osassa muotoja jälkitavun vokaalin voi kuitenkin katsoa olevan osa alkuperäistä sanavartaloa.

Esitämme, että näiden kieltohakuisten indefiniittipronominien muodostusmallina ovat toimineet suomen pronominit ja adverbit mikään, kukaan, missään sekä koskaan, joita ei ole muodostettu interrogatiivipronominista tai adverbistä lisäämällä liitepartikkelia -kAAn, *mikäkään, *kukakaan, *missäkään, *koskakaan, vaan sulauttamalla liitepartikkeli sanavartaloon. Suomen kielen -kAAn-liite on Räisäsen (1996) mukaan syntynyt suomen kielen erilliskehityksen aikaan, ja missään-tyyppiset muodot ovat kehittyneet vielä näitäkin myöhemmin. Inarinsaamen $-(V) n$-loppuiset muodot eivät siis voi olla kovin vanhoja, mihin viittaakin se, että esim. mihheen- ja kihheen-pronominien essiivissä ja partitiivissa on mahdollinen vain säännönmukainen -gin-liitteinen muoto: manengin, mađegin (ei *manneen, mađđeen) 'minään, mitään', kenengin, keđegin (ei *kenneen, keđđeen) 'kenenäkään, ketään', vrt. sm. kukaan : ketään mutta kenenkään (InSaS: 133).

Myös koltansaamen Paatsjoen murteessa esiintyy kielteisten indefiniittipronominien

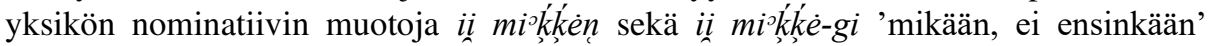
(KLpS: 249). Nämä on ilmeisesti lainattu inarinsaamesta, mihin viittaa se, että muotoja ei tavata muissa koltansaamen murteissa eikä Paatsjoen murteessa tavata muista pronomineista tai adverbeista muodostettuja näiden kaltaisia kieltohakuisia pronomineja.

\subsection{Skandinaavisista kielistä lainattuja elementtejä}

nor. bare, ber(r)e, ru. bara 'vain' (Qvigstad 1893: 122; LpWsch: 4676; Sammallahti 1998: 231)

Po beare 'ainoastaan, yksinomaan', esim. gii beare 'kuka vain, kuka tahansa' (LpWsch: 4868; Sammallahti 1993: 33)

In peri 'vain, yksinomaan' (InSaS: 68), esim. Tast tiettim, et sátáččij tábáhtuđ mii peri 'siitä tiesin, että saattaisi tapahtua mitä vain' (SIKOR)

Tähän yhteyteen kuuluvat myös vain adverbeinä toimivat

E barre 'vain' (LpWsch: 4676; SüdLpW: 291; SydSaO: 30)

U barra 'vain, ainoastaan' (MalåLpW: 11; Barruk 2018: 31)

Pi ber bär 'vain, ainoastaan' (LpWsch: 4676; Wilbur 2020)

Lu päre pära päru 'vain, ainoastaan' (LuLpW: 804)

Levikin perusteella vaikuttaa siltä, että vaikka elementti onkin peräisin skandinaavisista kielistä, sen käyttö indefiniittipronominin osana pohjois- ja inarinsaamessa on suomen vaikutusta, vrt. kuka vain. Suomen vaikutukseen viittaa myös se, että tällaista beare-sanan käyttöä tavataan Norjan puolelta kerätyistä pohjoissaamen kieliaineistoista vain harvoin (LpD I: 296; SIKOR).

T.I. Itkonen (KLpS: 357) on yhdistänyt kildininsaamen adverbiaalin pere 'perin, sangen' pohjoissaamen beare yhteyteen. Etymologia vaikuttaa kuitenkin epävarmalta sekä merkityksensä takia että siksi, ettei sanaa esiinny kildininsaamen länsipuolella puhutussa koltansaamessa. 
nor. einn 'yksi' ene 'ainoa' (Qvigstad 1893: 83; SSA s.v. ainoa; LpWsch: 156; Sammallahti 1998: 128)

E aajne(h), aajnehke 'ainoa (lapsi)' (SüdLpW: 199; SydSaO: 18)

U ájnna 'ainoa' (Barruk 2018: 23; MalåLpW: 3)

Pi ájdna 'ainoa' (Halász 1896: 1; Wilbur 2020)

Lu ájnna 'ainoa' (LuLpW: 6-7; Kintel 2012)

Po áidna 'ainoa' (LpD I: 21)

SSA esittää, että sanat olisi lainattu suomen kielen välityksellä samoin kuin samaa merkitsevät labiaalivokaalin sisältävät sanatkin (ks. 3.1, ainoa ainova). Pidämme näitä kuitenkin erilähtöisinä jälkitavun vokaalin labiaalisuuden ja sanan levikin perusteella (ks. LpWsch: 156, 157).

Pohjois- ja luulajansaamessa esiintyy myös rakenne juohke áidna juohkka ájnna joka merkitsee 'joka ainoa, jokaikinen'. Tämä rakenne on lainattu suomen rakenteesta joka ainoa:

Soai bissáneigga juohke áidna báikái gos orui buorre oaggut.

'He kaksi pysähtyivät joka ainoaan paikkaan, jossa vaikutti olevan hyvä onkia.' (SIKOR)

Siebrre sihtá aj sierraláhkáj gijttet juohkka ájnna guhti le prosjevtan viehkken årrum.

'Seura haluaa erikseen kiittää joka ainoaa, joka on ollut apuna projektissa.'

(SIKOR)

nor. hver, hvert 'joka, jokainen' (Bergsland 1946: 110)

E fierhte, fierhne 'jokainen' (LpWsch: 1041; SüdLpW: 492; Bergsland 1946: 110; SydSaO: 77)

U feärtta 'jokainen' (MalåLpW: 39; Barruk 2018: 54)

Pi färrta 'kaikki, jokainen' (Halász 1896: 15; LpWsch: 1041; Wilbur 2020)

Lu fert, esim. fert slájas 'joka lajia' (LuLpW: 71; Kintel 2012)

Po feara, esim. feara gii 'kuka tahansa' (LpD I: 661; Nickel \& Sammallahti 2011: 129-130)

Eteläsaamessa esiintyy myös indefiniittipronomini fiere-guhte 'jokainen' (SydSaO: 77), joka on käännöslaina norjan indefiniittipronominista hver og en 'jokainen' (Bergsland 1946: 110).

nor. kvar 'joka, jokainen' (vrt. yllä)

E kööre kääre 'joka, jokainen', esim. köörem biejjiem 'joka päivä' (SüdLpW: 816; SydSaO: 163)

nor. ja ru. 'man' (Sammallahti 2007: 105)

Indefiniittipronomininomaisena voi tietyin varauksin pitää myös mm. piitimen-, luulajan- ja pohjoissaamessa esiintyvää ihminen-substantiivin käyttöä. Kyseessä on siis 
skandinaavisten kielten passiivisen pronominin man (< 'mies') mallin mukainen käännöslaina, joka on kopioitu läntisten saamelaiskielten 'ihmistä' tai 'miestä' merkitsevään sanaan. Sanaa käytetään, kun puhutaan yleistäen kenestä tahansa ihmistarkoitteisesta referentistä, ja se vastaa jokseenkin käytöltään suomen nollapersoonaa tai passiivia (Korhonen 1970: 143; Sammallahti 2007: 105).

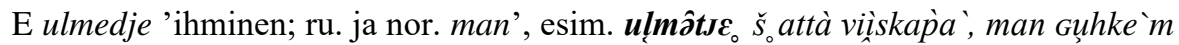
jă $\ddot{a}^{\circ}$.là 'sitä viisaammaksi tulee, mitä pidempään elää.' (SüdLpW: 1379; Collinder 1942: 50)

Pi almatj 'ihminen; ru. ja nor. man' (Wilbur 2020), esim. dä ij del almatj sida nagin sadjáj vuällget 'sitten ei ilmeisesti halua lähteä mihinkään' (Wilbur 2014: 239)

Lu almasj ulmusj 'ihminen; ru. ja nor. man' (LuLpW: 1328; Spiik 1989: 62; Kintel 2012)

Po olmmoš 'ihminen; ru. ja nor. man' (Nielsen 1926: 301; Korhonen 1970: 143; Sammallahti 2007: 105), esim. olmmoš oahppá nu guhká go eallá. 'Oppia ikä kaikki' (Nielsen 1926: 301)

Yllättävää on se, että tätä rakennetta ei enää nykyisin tavata eteläsaamessa (Richard Kowalik \& David Kroik, henkilökohtainen tiedonanto, 3.3.2021).

nor. mange 'moni' (Qvigstad 1893: 232; LpWsch: 3774)

Lu máyga 'moni' (LuLpW: 498)

Po mánga 'moni' (LpD II: 636; LpWsch: 3744)

In mangâ 'moni' (InLpW: 2322; InSaS: 50)

Ko mäygg 'moni' (KLpS: 239; KoSaS: 71)

Sammallahti (1998: 254) pitää sanoja kantaskandinaavisina lainoina, mitä ne eivät voi olla, koska sanassa ei ole tapahtunut denasalisaatiota. Denasalisaatio on alkanut länsikantasaamessa saamelaisen kantakielen hajottua ja levinnyt myöhemmin myös itään inarin- ja koltansaameen, esim. ksa. *jeajkē > Po jeaggi Ko jeä'ğğ (Sammallahti 1998: 193-194; Aikio 2009: 248). Mikäli sana olisi lainattu jo kantasaameen, odotuksenmukainen nykyasu olisi Po **mágga Ko **magg, vrt. E vaegkie Po vággi < ksa. *vāyke < kskand. *wanga- (Aikio 2009: 286). Myös levikki viittaa tuoreempaan lainaan.

nor. noen 'jokin', ru. någon id. (Qvigstad 1893: 243; LpWsch: 4101)

E naakene, naagede 'jokin, joku' (LpWsch: 4101; SüdLpW: 958; SydSaO: 200)

U nágan 'jokin, joku' (MalåLpW: 98: Barruk 2018: 108)

Pi nágan nagan, nágin 'jokin, joku' (LpWsch: 4101; Wilbur 2014: 140; 2020)

Lu nágin 'jokin, joku' (LpWsch: 4101; LuLpW: 571; Kintel 2012)

nor. same 'sama', ru. samma id. (Qvigstad 1893: 331; LpWsch: 6204)

E seamma 'sama' (LpWsch: 6204; SüdLpW: 1122; SydSaO: 251)

U siämmá sammá såmmá 'sama' (MalåLpW: 133; Barruk 2018: 257)

Pi sämmi 'sama' (Wilbur 2020) 
Lu sammi sabbmi 'sama' (LpWsch: 6204; LuLpW: 1048; Kintel 2012)

Po seammá 'sama' (LpD III: 622; Nickel \& Sammallahti 2011: 142)

In siämmáá siämmáš 'sama; samanlainen; yhdentekevä, samoin' (InLpW: 4099; InSaS: 87)

Ko seämma 'sama' (KLpS; 481; KoSaS: 111)

nor. ymis, ymse 'monenlainen, erilainen'" (Qvigstad 1893: 251)

E ovmessie ummese 'monenlainen, usea, sekalainen' (SüdLpW: 1386; SydSaO: 222)

U uvmassie 'kaikenlainen, erilainen, paljon' (MalåLpW: 146; Barruk 2018: 157)

Pi umasse 'kaikenlainen, paljon; erilainen' (Halász 1896: 86; Wilbur 2020; Lehtiranta 1992: 139)

Lu umassēe 'kaikenlainen' (LuLpW: 1329)

\subsection{Venäjästä lainattuja elementtejä}

весь 'kaikki, kokonaan'

Ko vee'zz rakenteessa puk vee'zz 'kaikki tyynni, kaikkialla' (KLpS: 736; KoSaS: 32)

Ki весь rakenteessa пугквесь 'kaikki tyynni, kaikkiaan, kaikkialla' (KLpS: 736; Antonova 2014: 234 )

SSA (s.v. visu) yhdistää nämä luulajansaamessa, pohjoissaamessa ja inarinsaamessa esiintyvään pronominiin (ks. 3.1, visu). Pidämme kuitenkin näitä eri lähtöisinä, sillä koltan- ja kildininsaamesta puuttuu lännempänä tavattava adverbinjohdin - $t$ (< ksa. -*htē). Lisäksi idässä partikkeli esiintyy aina indefiniittipronominin puk 'kaikki' kanssa.

жсе

Inarin-, koltan-, akkalan-, kildinin- ja turjansaamessa esiintyy partikkeli še $\sim \check{z} e$ 'myös', joka on lainattu venäjän korostavasta partikkelista же (KLpS: 546). Tämän partikkelin avulla voidaan muodostaa myös 'samaa' merkitseviä indefiniittipronomineja demonstratiivipronomineista. Tällainen partikkelin käyttö on käännöslainaa venäjän rakenteesta mom же 'sama', jossa esiintyy demonstratiivipronomini sekä partikkeli же:

Ko tõt-še 'sama' (KLpS: 546)

Ki тэдт шэ 'sama' (Antonova 2014: 317)

T taḿme žع aije 'samaa laulua', tannešc b 'ii 'samaan aikaan' (Szabó 1967: 136, 142)

Venäjän mallin mukaan (так же 'samoin', такой же 'samanlainen') voidaan muodostaa myös adverbejä ja adjektiiveja:

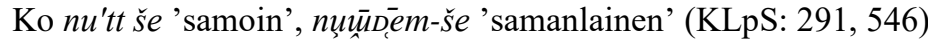

A nitt-še samoin' (KLpS: 291), mokom_žc 'samanlainen' (Kert \& Zaikov 1988: 20)

Ki néşšse-še 'samoin' (KLpS: 291), мугка шэ 'samanlainen' (Antonova 2014: 356)

T niptt-še 'samoin', na $a_{i}$ tem-že 'samanlainen' (KLpS: 291, 546)

\footnotetext{
${ }^{4}$ Sanan ruotsin vastine ömse merkitsee nykykielessä 'molemmat'.
} 
кажжый (murt. кажный) 'joka, jokainen' (KLps: 96)

A kāžnoj 'jokainen', esim. nu jarka leijiš kāănoist jijiś pohce liịjiš 'no ennen jokaisella oli omia poroja' (Kert \& Zaikov 1988: 16)

Ki kāžneñ dt'šs 'jokainen', ка̄жнэ id., esim. кажнэ пе̄ййв 'joka päivä' (KLpS: 96; Antonova 2014: 84)

T kāžnịầi 'jokainen, joka' (KLpS: 96)

лищь 'vain, pelkästään' (KLpS: 196)

Ki льь (ш)шэ 'vain, ainoastaan; kunhan, saati', esim. kie lišša 'kuka hyvänsä', lišša $m \bar{\imath}$ 'mikä tahansa' (KLpS: 196; Antonova 2014: 158)

несколько 'muutama, jokunen' (Harder 2010: 52)

T n'eskol'k 'muutama'., esim. n'eskol'k jell'ịmịt 'muutamia eläimiä' (Szabó 1967: 140)

ни- '-kAAn, edes', esim. никmо 'ei kukaan', ничmo 'ei mikään' (KLpS: 280)

Ko ni, esim. (ij) ni kii 'ei kukaan' (KLpS: 280; Feist 2010: 258-261)

A ni, esim. niki 'ei kukaan', nimi 'ei mikään' (KLpS: 280; Zaikov 1987: 128)

Ki ни, еsim. нике 'ei kukaan', ними 'ei mikään' (KLpS: 280; Kert 1971: 177; Antonova 2014: 186, 187)

T n'i, esim. n'ik'e 'ei kukaan', n'im 'i 'ei mikään' (KLpS: 280; Tereškin 2002: 112)

Turjansaamessa kieltohakuiseen pronominiin liittyy usein myös kieltohakuinen partikkeli -gin, esim. ì ni_kie-gin, 'ei kukaan' (KLpS: 280).

-нибудь, esim. кто-нибудь 'joku', что-нибудь 'jokin' tai karjalan -nih, esim. kennih 'joku'

In -nii, esim. kiinii 'joku', miinii 'jokin' (InLpW: 2653; InSaS: 57)

Ko -ne, esim. kii-ne 'joku', mii-ne 'jokin' (KLpS: 280; Feist 2010: 258-260)

A -ni, esim. kini 'joku', mini 'jokin' (KLpS: 280; Zaikov 1987: 127)

$\mathrm{Ki}$-не, еsim. ке-не ке-ни 'joku', ми-не 'jokin' (KLpS: 280; Kert 1971: 177; Antonova 2014: 91, 167)

T -ni, esim. kie-ni 'joku' (KLpS: 280)

Inarinsaamessa -nii-liitepartikkeliin voi liittyä lisäksi kielteinen liite -gin -gen '-kAAn', esim. miiniigin. Yhdessä ne eivät kuitenkaan muodosta kielteistä ilmausta, vaan pronomini merkitsee pikemmin samantekevyyttä. (InLpW: 2653.) Vastaavanlaisia yhdysliitteisiä muotoja tavataan myös suomesta, joskaan ne eivät ole erityisen tavallisia, esim. jotakinkaan 'mitä tahansa, edes jotakin'. Suomi on saattanut toimia mallina inarinsaamen muodoille. On kuitenkin huomattava, että suomen vastaavien muotojen yleisyyttä ei ole tutkittu, joten vaikutusta on vaikea todentaa.

Venäjällä puhuttavissa itämerensuomalaisissa kielissä esiintyy äänteellisesti ja semanttisesti vastaava indefiniittipronomineja muodostava jälkiliite -ńi -ni. Itämerensuomen indefiniittipronominien lainaelementtejä tutkinut Alvre esittää (2002: 162), että aines on sama kuin kielteisiä indefiniittejä muodostava etuliite ńi- $\sim n i-(<$ ven. $н u$, ks. 
yllä), joka on muuttunut suffiksiksi. Myöhemmin saman selityksen tarjoaa myös Blokland, joka kuitenkin lisää, että suffiksin taustalla voi olla venäjän rakenne чmo/кmo был ни был 'onpa se mikä/kuka vain' (Bloklandin 2012: 4 mukaan Gilojeva 2001: 43). Sen enempää Alvre kuin Bloklandkaan eivät kuitenkaan selitä oletettua semanttista kehitystä kielteisestä epämääräiseksi ('ei mikään' > 'jokin'), eritoten kun varsinainen kielteinen prefiksikin on säilynyt.

Epämääräisyyden $-n ́ i \sim-n i$ onkin merkityksen ja pronomininjälkeisen sijaintinsa vuoksi luultavasti pikemmin lainattu venäjän suffiksista -нибудь (Hienonen [Karjalainen] 2009: 30; 2010: 286; 2019: 68; ks. van Alsenoy \& van der Auwera 2015: 535). Saamelaiskieliin tunnus on voitu lainata samaan tapaan joko venäjästä tai karjalan kautta indefiniittipronominitunnuksesta -nih. Jälkimmäistä lainautumisreittiä tukee se seikka, että saamelaiskielten aineistoissa tunnuksesta ei tavata pidempää -nibut-varianttia.

1900-luvun loppupuolella kerätyssä turjansaamessa esiintyy myös muotoja, kuten k'en 'itta 'joku' ja momnitta 'jokin' (Tereškin 2002: 112), jotka vaikuttavat sisältävän edellä mainitun partikkelin lisäksi myös venäjästä lainatun indefiniittipronomineissa käytetyn partikkelin -mo [to], esim. кmo-mo 'joku', чmo-mo 'jokin'. Anonyymi vertaisarvioija esittää, että kyseessä voisi olla säännönmukaisempi venäjän -нuбydb-asun jatkaja, joka vasta myöhemmin olisi typistynyt muotoon $-n i(<-n ́ i t t(a)<-n ́ i b u t$ '). Emme pidä tätä kehitystä realistisena siitä syystä, että olemme löytäneet elementin -n'itta/-nitta ainoastaan yhdestä lähteestä, joka perustuu 1900-luvun loppupuolelta kerättyyn aineistoon, kun taas vanhemmat lähteet ovat yksinomaisesti elementin -ńi/-ni kannalla. Ei myöskään vaikuta todennäköiseltä, että - $n$ 'itta/-nitta olisi tuore laina venäjän partikkelista -нибудь, sillä tällöin turjansaameen olettaisi muotoa -nibut'.

Myös pohjoissaamen ruijansaamen itämurteissa sekä itäisissä merisaamelaismurteissa tavataan indefiniittipronomineja, jotka on muodostettu interrogatiivipronomineista partikkelin $n u$ 'niin' avulla, esim. mii 'mikä' > mii nu 'jokin', gii 'kuka' > gii nu 'joku' (LpWsch: 3850; LpD III: 124-125). T.I. Itkonen (KLpS: 280) rinnastaa nämä pohjoissaamen indefiniittipronominit yllä mainittujen itäisempien saamelaiskielten indefiniittipronomineihin. Vaikka näiden pronominien merkitykset ja johtotapa vastaavat toisiaan, on rinnastus hylättävä, sillä pohjoissaamen partikkelin vokaali ei vastaa itäisempien saamelaiskielten partikkeleiden vokaalia. Sitä vastoin pohjoissaamesta on lainattu inarinsaamen läntiseen murteeseen indefiniittipronomini maid-nuиvt 'yhtä ja toista' (InLpW: 2442).

Esitämme että pohjoissaamen indefiniittipronominien johtotavan mallina toimi karjalan kieli. Karjalan indefiniittipronomineissa kennih 'joku' ja mikänih 'jokin' esiintyvä partikkeli -nih on kansanetymologisesti analysoitu samaksi elementiksi kuin karjalan partikkeli niin, joka saa samanlaisia merkityksiä kuin pohjoissaamen partikkeli $n u$, esim. krj. niin äijän 'niin paljon', Po nu ollu. Pohjoissaamen länsimurteissa tämänmerkityksisten indefiniittipronominien muodostamiseen ei ole yhtä keinoa, vaan niiden merkityksiä ilmaistaan useilla eri rakenteilla, partikkeleilla ja pronomineilla, esim. soames báikái 'johonkin paikkaan' sekä juoga 'jokin'. Tästä syystä on ollut houkuttelevaa lainata karjalasta malli, jonka avulla voidaan säännönmukaisesti muodostaa indefiniittipronomineja kaikista interrogatiivivartaloista. 
Yllä esitetylle kansanetymologiselle käännöslainalle voidaan esittää paralleeli suomen kielestä. Suomen itämurteissa partikkelia niin voidaan käyttää vahvistavana partikkelina kielteisessä rakenteessa ei niin mitään, ei niin kukaan, ei niin missään. Hakulinen (1999: 69) pitää mahdollisena, että tällainen suomen yleiskielestä poikkeava partikkelin käyttö olisi lainattu venäjän kielen kielteisestä partikkelista $н u$ '-kAAn, edes'. Houkuttelevampaa on kuitenkin ajatella, että kyseessä on kansanetymologinen lainaus karjalan kielestä. Karjalassa esiintyy venäjästä lainattu rakenne ei ni mitä 'ei mitään', ei ni konsa 'ei milloinkaan', jossa interrogatiivipronominien ja kysymyssanojen eteen liittyy kielteisen interrogatiivipronominin tunnus $n i$. Tämän rakenteen rinnalla karjalassa esiintyy myös vanhempi rakenne ei mitänä 'ei mitään' Lisäksi näiden rinnalla tavataan näiden kahden rakenteen yhdistelmä ei ni mitänä 'ei mitään', ei ni konsana 'ei milloinkaan' (Olga Karlova, henkilökohtainen tiedonanto, 26.5.2015). Suomen itämurteiden rakenne ei niin missään on mahdollisesti lainattu juuri tällaisesta kahden rakenteen yhdistelmästä.

одинокий 'yksinäinen', одной 'yksi' (KLpS: 917)

Ko o'dinak o'dinakai 'ainut, ainoa' (KLpS: 917; KoSaS: 2)

Ki od́nnāGəi 'ainoa' (KLpS: 917)

T jednai, esim. ušš must jednai rēedD jellă 'minulla ainoatakaan sukulaista ei ole' (Szabó 1967: 146); jednaj tōni nịit teśt jellak 'ainoakaan tyttäresi täällä ei ole' (Szabó 1968: 56)

xоmь esim. хоть кто 'vaikka kuka, kuka tahansa' (KLpS: 42)

Ko hå't 'vaikka', esim. hå't mâi'd 'vaikka mitä' (KLpS: 42; KoSaS: 141)

Tiedossamme ei ole tapauksia, joissa A $\chi o_{i} t$ 'vaikka, edes', Ki xoдmb 'vaikka, edes' tai T ot 'vaikka, edes' (KLpS: 42; Antonova 2014: 327) olisivat käytössä samantekevyyden pronominien muodostamisessa, mutta pidämme niiden olemassaoloa mahdollisena venäjän kielen mallin vuoksi. Myös karjalassa esiintyy tällaista hot partikkelin käyttöä, esim. En lähe hot mi ois. 'En lähde, vaikka mikä olisi.' (KKS: s.v. hot).

\section{$4 \quad$ Yhteenvetoa ja keskustelua}

Vaikka emme olekaan tutkineet omaperäisten ja lainattujen indefiniittipronominien sekä niitä muodostavien elementtien osuuksia saamelaiskielissä, näyttää siltä, että suuri osa tällaisista sanoista on lainattu ympäröivistä kielistä. Indefiniittipronominien joukossa on niin lainattuja lekseemejä ja sanavartaloita (esim. In mu-, Po seammá), suoraan lainattuja taivutettuja muotoja (Ko muиda muuđa, PoJuk yhtä $\sim i h t a)$ kuin käännöslainoja, joissa yksi tai useampi osa indefiniittisestä ilmauksesta on mallinnettu toisen kielen mukaan. Yleisiä käännöslainaindefiniittejä ovat interrogatiivipronominista ja fokuspartikkelista muodostetut pronominit. Joskus partikkeli voi esiintyä kielessä indefiniittipronominin ulkopuolella myös itsenäisenä sanana, joskus taas partikkelia ei käytetä muissa yhteyksissä. Lainavartaloiden kohdalla on tavallista yleisempää, että 
taivutus on epäsäännöllistä tai vaillinaista siten, että osa sijamuodoista puuttuu tai taivutusmuotoja ei muodosteta täysin säännönmukaisesti.

Vaikuttaa siltä, että indefiniittisten pronominien luokka on verrattain avoin, eli siihen on helppo lainata pronomineja. Toisaalta osa ilmauksista saattaa olla pikemmin tilapäismuodosteita, jotka voivat melko helposti jäädä pois käytöstä tai jotka eivät vakiinnu kieleen. Tätä tukee myös se huomio, että saamelaiskieliin on lainattu suurin piirtein samatarkoitteisia pronomineja uudelleen ja uudelleen. Esimerkiksi koltansaameen on vanhemman pronominin måtam rinnalle on lainattu venäjästä kii-ne ja myöhemmin suomesta joku, ja pohjoissaamessa elävät rinnakkain lähimerkityksiset pronominit, jotka muodostetaan eri tahoilta lainatuilla partikkeleilla vaikko, feara, sahte, beare ja ihkinassii. Vastaavia esimerkkejä löytyy pitkään venäjän kanssa kontaktissa olleista itämerensuomalaisista kielistä, kuten karjalasta, vatjasta ja vepsästä, joihin on lainautunut venäjästä paljon indefiniittipronomineja muodostavia elementtejä (Alvre 2002).

Yleisellä tasolla voi myös sanoa, että saamelaiskielet eivät ole lainanneet yhtä voimakkaasti kaikista kontaktikielistään; venäjästä ja skandinaavisista kielistä on lainatut vähemmän kuin suomesta. Tämä voi johtua siitä, että suomen ja saamen indefiniittien järjestelmät muistuttavat jo kielisukulaisuuden vuoksi enemmän toisiaan. Vaivatta segmentoitava morfologia lainautuu helpommin kuin monimutkaisemmat, syntaktiset rakenteet, kuten ruotsin någon som helst tai norjan en eller annen.

Voi myös kysyä, minkälaisia indefiniittisiä pronomineja saamelaiskielissä on käytetty ennen lainaperäisiä ilmaisuja. Esitämme, että tätä asiaa valottavat Kuolan niemimaalla puhutut saamelaiskielet (KLpS: 114, 247) sekä eteläsaame, joissa paljaita interrogatiivipronomineja käytetään tietyissä lauseyhteyksissä indefiniittisinä, esim. E jis gie båata 'jos joku tulee', "jos kuka tulee" (SüdLpW: 131; Bergsland 1946: 108), ij geä daab naajkeb sïjth doåriedidh 'ei kukaan halua seurata tätä hidasta' (Blokland \& Inaba 2015: 389). Myös itämerensuomen interrogatiiveilla on aiemmin ollut enemmän vastaavaa käyttöä, esim. sm. ken ('eräs, joku') tuopi kerran, ken kaksi; va. kõik tämä vargassi, tšen mitä vaa tšähsi 'kaiken hän varasti, mitä joku vain käski' (Ojansuu 1922: 94-95; Alvre 1982: 46-47). Varhaisempaa kehitystä ovat todennäköisesti myös eteläsaamen partikkelista $a k t(e)$ (<'yksi') ja interrogatiivipronominista muodostuneet indefiniitit, esim. mij-akteh 'jokin', akte-mij 'joku, jokin, mikä t. kuka tahansa' (LpWsch: 3850; SüdLpW: 131), vrt. udmurtin ог-кин 'joku', "yksi-kuka" ja niittymarin икмо 'jokin', "yksi-mikä”. Ei voi kuitenkaan sanoa, että nämä muodosteet palautuisivat jo uralilaiseen kantakieleen, sillä indefiniittien kehittyminen lukusanaa 'yksi' merkitsevän lekseemin avulla on typologisesti varsin yleistä (Haspelmath 1997: 183-184).

Emme käsitelleet tässä artikkelissa joitakin löytämistämme indefiniittipronomineista, koska niille ei ollut ainakaan tässä vaiheessa osoitettavissa laina-alkuperää tai niiden suhde lainanantajakielen elementteihin on epäselvä. Viimeksi mainittuun ryhmään lukeutuu mm. seuraava sanue:

Ko täättas 'tahansa', esim. mii täättas 'mikä tahansa', måkam tättaz leäkkaz 'mitä tahansa lienevätkin', "millaiset tahtokoot olkoot" (KLpS: 576; KoSaS: 124)

A dates 'tahansa', esim. vŭoiji koz_dates 'ajoi minne tahansa' (Kert \& Zaikov 1988: 18) 


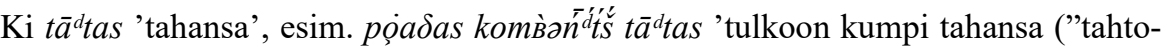
koon")' (KLpS: 576)

T tātta 'tahansa', esim. mì tātta 'mikä tahansa' (KLpS: 576)

Sanueella on selvästi yhteys ims. sanoihin sm. tahansa krj. tahto 'tahansa' (ks. SKES s.v. *taha-; SSA s.v. tahansa). Kyseinen indefiniittipronomini ei vaikuta erityisen vanhalta, mihin viittaa myös se, että niihin kytkeytyvä 'tahtomista' merkitsevä verbi, esim. koltansaamen täättad on kohtalaisen tuore ims. laina (SSA s.v. tahtoa).

\section{$5 \quad$ Lopuksi}

Olemme luoneet tässä artikkelissa yleissilmäyksen saamelaiskielten lainaperäisiin indefiniittipronomineihin ja pronominaalisiin elementteihin. Indefiniittipronomineja on käsitelty aiemmassa tutkimuksessa vaihtelevasti; perusteellisimmin indefiniittipronomineja on kartoitettu pohjoissaamesta, jota on tutkittu muutenkin enemmän kuin sisarkieliään. Pienemmistä saamelaiskielistä indefiniittipronomineja on tutkittu vähän tai ei lainkaan, ja useissa kieliopeissa on rajoituttu pronominien luettelointiin, lyhyisiin käännöksiin ja taivutuskaavojen esittelyyn. Indefiniittisten pronominien ja niitä muodostavien elementtien lainaperäisyyteen ovat toki kiinnittäneet huomiota jo aiemmat tutkijat, mutta yleisesitystä aiheesta ei ole tehty.

Haspelmath toteaa, että indefiniittipronomineilla on perinteisesti ollut vähäinen rooli deskriptiivisessä kielitieteessä mutta niillä on monia mielenkiintoisia piirteitä (1997: 1). Saamelaiskielten lainaperäisten indefiniittien osalta voidaan todeta, että molemmat toteamukset pitävät paikkansa. Miksei indefiniittipronomineja ole sitten tutkittu enemmän? Yhtenä syynä tähän lienee se, että saamen kieliä osaavista tutkijoista ei ole maailmassa runsaudenpulaa, ja monet keskeisemmätkin kieliopin kohdat ovat useista saamelaiskielistä yhä kartoittamatta. Toisaalta monet lainaperäiset indefiniittipronominit ovat muodostukseltaan hyvinkin läpinäkyviä, joten niiden ei ole ehkä katsottu tai ajateltu tarvitsevan tarkempaa perehtymistä.

Aineistoesimerkeistämme on kuitenkin havaittavissa, että kieliopillisissa kuvauksissa annetut yhden sanan mittaiset käännökset valtakielelle eivät usein kuvaa pronominin koko käyttöalaa. Esimerkiksi suomen lauseen Täällä ei ole käynyt kukaan voi kääntää koltaksi käyttämällä kieltohakuista indefiniittiä ni kii 'kukaan'. Yhden sanan käännöksen perusteella voisi ajatella, että ni kii voisi käyttää myös lauseen Onko kukaan käynyt täällä käännöksessä, mutta se ei ainakaan perinteisesti ole ollut mahdollista. Myöskään venäjässä sanan никто 'kukaan' käyttö ei ole mahdollista ei-kielteisissä kysymyksissä, vaan sen sijaan käytetään indefiniittipronominia кто-нибудb, esim. Tbl видел что-нибудь? 'Näitkö mitään?' (Haspelmath 1997: 65). Kieltohakuisen indefiniitin ni kii käyttö ei-kielteisissä kysymyksissä voi kuitenkin muuttua hyväksytyksi suomen kielen vaikutuksesta, sillä jo nykyisin vastaavissa kysymyslauseissa voidaan käyttää kieltohakuista indefiniittiä kii-kaan, kuten käy ilmi seuraavasta lauseesta:

Mätt'ti-go tu'nne kii-kaan?

'Opettiko sinulle kukaan?' (Kotus 17461_1ez, 00:34:29) 
Lainaperäisten indefiniittien katsauksessamme tuli esille myös joitakin lisätutkimusta kaipaavia elementtejä, jotka ovat jääneet aiemmin kokonaan tai osittain vaille huomiota. Esimerkiksi inarin- ja koltansaamen $m u(u)$-alkuisten indefiniittisten pronominien merkitys ja distribuutio verrattuna lähimerkityksisiin sanoihin eres ja jee'res 'muu, toinen' ja koltansaameen lainattu joku jonku -pronomini olisi tutkittava parem$\min$.

Saamelaiskielten indefiniittipronomineissa riittää siis vielä työsarkaa. Yksi mahdollisuus olisi soveltaa Haspelmathin (1997) tutkimusta ja tarkastella saamelaiskielten indefiniittejä Haspelmathin kehittämän implikationaalisen kartan avulla (mts. 63-64). Karttaa on soveltanut onnistuneesti vepsään Heini Hienonen, joka toteaakin yhtenä tuloksenaan sen, että vaikka vepsän skeemalla on yhteistä suomen ja venäjän vastaavan kanssa, sille on joka tapauksessa kehittynyt omaleimainen, sekä suomesta että venäjästä erottuva järjestelmä (2010: 290-291). Näin ollen voi ajatella, että myös saamelaiskielten indefiniittien järjestelmistä löytynevät analyysin tuloksena omat piirteensä, jotka erottavat ne kontaktikielistään ja lähisukukielistään. Tällaisesta tutkimuksesta hyötyisivät niin typologit kuin ainakin välillisesti myös kielenoppijat.

\section{Kielten lyhenteet}

$\begin{array}{ll}\mathrm{E}=\text { eteläsaame } & \mathrm{T}=\text { turjansaame } \\ \mathrm{U}=\text { uumajansaame } & \text { ims. = itämerensuomi } \\ \mathrm{Pi}=\text { piitimensaame } & \mathrm{krj} .=\text { karjala } \\ \mathrm{Lu}=\text { luulajansaame } & \mathrm{ksa} .=\text { kantasaame } \\ \mathrm{Po}=\text { pohjoissaame } & \text { kskand. = kantaskandinaavi } \\ \quad \text { Juk = Jukkasjärvi } & \text { nor. = norja } \\ \text { In = inarinsaame } & \text { ru. = ruotsi } \\ \mathrm{Ko}=\text { koltansaame } & \text { sm. = suomi } \\ \mathrm{A}=\text { akkalansaame } & \text { va. = vatja } \\ \mathrm{Ki}=\text { kildininsaame } & \end{array}$

\section{Lähdeluettelo}

1. Aikio, Ante 2009: The Saami Loanwords in Finnish and Karelian. Väitöskirja. Oulu: Oulun yliopisto.

2. Van Alsenoy, Lauren - van der Auwera, Johan 2015: Indefinite pronouns in Uralic languages. - Matti Miestamo, Anne Tamm \& Beáta Wagner-Nagy (toim.) Negation in Uralic Languages, s. 517-546. Amsterdam: Benjamins.

3. Alvre, Paul 1982: Läänemeresoome indefiniitpronoomeneist. - Voces amicorum Sovijärvi. In honorem Antti Sovijärvi septuagesimum annum agentis die XXII mensis aprilis anno MCMLXXXII s. 45-54. SUST 181. Helsinki: Suomalais-Ugrilainen Seura.

4. Alvre, Paul 2002: Russische Lehnelemente in Indefinitpronomen und -adverbien der ostseefinnischen Sprachen. - Linguistica Uralica 38 s. 161-164.

5. Antonova 2014 = Антонова, Са̄нндрэ: Самь-Руши саннґънэххьк. Саамско-Русский словарь. Мурманск: Лема. 
6. Barruk, Henrik 2018: Báhkuogirjjie Ubmejesámien-dáruon| Dáruon-ubmejesámien. Kanaanstiftelsen i Sverige.

7. Bartens, Hans-Hermann 1980: Die Verwendung von Potential und Konditional im Lappischen. SUST 177. Helsinki: Suomalais-Ugrilainen Seura.

8. Bergsland, Knut 1946: Røros-lappisk grammatikk. Et fors $\phi k$ på strukturell språkbeskrivelse. Oslo: Aschehoug.

9. Bergsland, Knut 1994: Sydsamisk grammatikk. Karasjok: Davvi Girji.

10. Blokland, Rogier 2012: Borrowability of pronouns: evidence from Uralic. - FinnischUgrische Mitteilungen 35 s. 1-34. Helmut Buske Verlag.

11. Blokland, Rogier - Inaba, Nobufumi 2015: Negation in South Saami. - Matti Miestamo, Anne Tamm \& Beáta Wagner-Nagy (toim.), Negation in Uralic Languages s. 377-398. Amsterdam: Benjamins.

12. Collinder, Björn 1942: Lappische Sprachproben aus Härjedalen. Uppsala: Almqvist \& Wiksell.

13. Feist, Timothy 2010: A Grammar of Skolt Saami. Väitöskirja. Manchester: University of Manchester, Faculty of Humanities.

14. Feist, Timothy 2015: A Grammar of Skolt Saami. SUST 273. Helsinki: Suomalais-Ugrilainen Seura.

15. Friis, J.A. 1856: Lappisk Grammatik: udarbeidet efter den finmarkiske Hoveddialekt eller Sproget, saaledes som det almindeligst tales i norsk Finmarken. Christiania: paa J. W. Cappelens Forlag.

16. von Gertten, Daniel Z. 2015: Huvuddrag i umesamisk grammatik. Masteroppgåve. Institutt for lingvistiske og nordiske studiar, Universitetet i Oslo.

17. Gilojeva, Natalia 2001: Karjalan kielen indefiniittisten pronominien muodostuminen. - Karl Pajusalu \& Jan Rahman (toim.), Õdagumeresoomõ ütistüseq. Läänemeresoome ühendusteed. Konvõrentś Põlvan 26. - 28. rehekuu 2000 s. 38-46. Võro Instituudi toimõtiseq 11.

18. Guttorm, Outi 2009: Adnominála demonstratiivapronomenat muhtin davvisámegiel teavsttain. - Dieđut 1/2009 s. 114-125.

19. Hakulinen, Lauri 1999: Luennot suomen kielen partikkeleista. Lauranto, Yrjö - Lehtinen, Tapani (toim.). Helsinki: Helsingin yliopiston suomen kielen laitos.

20. Halász, Ignácz 1896: Pite Lappmarki szótár és nyelvtan. Rövid Karesuandói lapp szójegyzékkel. Svéd-lapp nyelv VI. Budapest: Magyar tudományos akadémia.

21. Hansegård, Nils Erik 1967: Recent Finnish Loanwords in Jukkasjärvi Lappish. Studia Uralica et Altaica Upsaliensia 3. Uppsala: Acta Universitatis Upsaliensis.

22. Harder (Behnke), Anja 2010: Die Struktur der Nominalphrase im Tersaamischen. Magisterarbeit. Humboldt-Universität zu Berlin.

23. Haspelmath, Martin 1997: Indefinite pronouns. Oxford: Oxford University Press.

24. Hienonen (Karjalainen), Heini 2009: Vepsän kielen kvanttoripronominit. Pro gradu -tutkielma. Helsingin yliopisto, humanistinen tiedekunta, suomalais-ugrilainen laitos.

25. Hienonen (Karjalainen), Heini 2010: The Implicational Semantic Map for Veps Indefinite Pronouns. - Linguistica Uralica 46 s. 281-292.

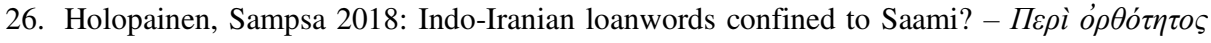

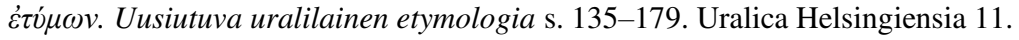

27. Holopainen, Sampsa 2019: Indo-Iranian borrowings in Uralic. Critical overview of the sound substitutions and distribution criterion. Väitöskirja. Helsingin yliopisto, humanistinen tiedekunta.

28. InLpW = Inarilappisches Wörterbuch 1986-1991. Toim. Erkki Itkonen, Raija Bartens \& Lea Laitinen. Lexica Societatis Fenno-Ugricae XX. Helsinki: Suomalais-Ugrilainen Seura. 
29. InSaS = Sammallahti, Pekka - Morottaja, Matti 1993: Säämi-suomâ sänikirje. Ohcejohka: Girjegiisá.

30. ISK = Auli Hakulinen, Maria Vilkuna, Riitta Korhonen, Vesa Koivisto, Tarja Riitta Heinonen ja Irja Alho 2004: Iso suomen kielioppi. Helsinki: Suomalaisen Kirjallisuuden Seura.

31. Itkonen, Erkki - Laitinen Lea (toim.) 1992: Inarinsaamelaisia kielennäytteitä. SUST 213. Helsinki: Suomalais-Ugrilainen Seura.

32. Juutinen, Markus 2016: Skalaariset partikkelit koltansaamessa. Pro gradu -tutkielma. Helsingin yliopiston suomen kielen, suomalais-ugrilaisten ja pohjoismaisten kielten ja kirjallisuuksien laitos.

33. Karjalainen, Heini 2019: Borrowing morphology: The influence of Russian on the Veps system of indefinite pronouns. - Sofia Björklöf \& Santra Jantunen (toim.), Multilingual Finnic. Language contact and change s. 55-87. Uralica Helsingiensia 14.

34. Kejonen, Olle 2020: North Saami, Čohkkiras variety (Sweden, Norway) - Language Snapshot. - Peter K. Austin (toim.), Language Documentation and Description 17, s. 178-185. London: EL Publishing. http://www.elpublishing.org/PID/194 (8.2.2021).

35. Kert $1971=$ Керт, Г. М.: Саамский язык (кильдинский диалект). Фонетика. Морфология. Синтаксис. Ленинград: Наука.

36. Kert \& Zaikov $1988=$ Керт, Г. М. - Зайков, П. М.: Образцы саамской речи. Петрозаводск: Карельский филиал АН СССР.

37. Kintel, Andreas 2012: Julevsáme-dárro báhkogirjje| Norsk-lulesamisk Ordbok. http://gtweb.uit.no/webdict/ak/smj2nob/index.html (28.2.2021).

38. $\mathrm{KKS}=$ Karjalan kielen sanakirja 2009. Helsinki: Kotimaisten kielten keskuksen verkkojulkaisuja 18. Verkkojulkaisu HTML. URN:NBN:fi:kotus-201113, ISSN: 1796-041X. http://kaino.kotus.fi/kks. Päivitettävä julkaisu. Päivitetty 26.2.2021 (viitattu 9.3.2021).

39. $\mathrm{KLpS}=$ Itkonen, T. I. 1958: Koltan- ja kuolanlapin sanakirja . Lexica Societatis FennoUgricae XV. Helsinki: Suomalais-Ugrilainen Seura.

40. Korhonen, Mikko 1970: Der Ausdruck des indefiniten Subjekts im aktivischen Satz des Lappischen. - Heikki Leskinen (toim.), Symposium über Syntax der uralischen Sprachen 15.-18. Juli 1969 in Reinhausen bei Göttingen s. 142-149. Göttingen: Vandenhoeck \& Rubrecht.

41. KoSaS = Sammallahti, Pekka - Moshnikoff, Jouni 1991: Suomi-koltansaame sanakirja . Ohcejohka: Girjegiisá.

42. Kotus $=$ Kotimaisten kielten keskuksen Suomen kielen nauhoitearkisto.

43. Laanest, Arvo 1990: Kommentar zu Seppo Suhonens Vortrag Über fremden Einfluss auf die Struktur der ostseefinnischen Sprachen. - Itämerensuomalaiset kielikontaktit: itämerensuomalainen symposium 7. kansainvälisessä fenno-ugristikongressissa Debrecenissä 27.8.1.9.1990 s. 105-107. Kotimaisten kielten tutkimuskeskuksen julkaisuja 61. Helsinki: Kotimaisten kielten tutkimuskeskus.

44. Lehtiranta, Juhani 1992: Arjeploginsaamen äänne- ja taivutusopin pääpiirteet. SUST 212. Helsinki: Suomalais-Ugrilainen Seura.

45. LpD = Nielsen, Konrad 1932-1962: Lappisk ordbok I-III. Grunnet på dialektene i Polmak, Karasjok og Kautokeino. Oslo: Aschehoug.

46. LpWsch = Lagercrantz, Eliel 1939: Lappischer Wortschatz I-II. Lexica Societatis FennoUgricae VI. Helsinki: Suomalais-Ugrilainen Seura.

47. LuLpW = Grundström, Harald 1946-1954: Lulelapsk ordbok. Uppsala: A.-B. Lundequistska Bokhandeln.

48. Magga, Ole Henrik - Magga, Lajla Mattsson 2012: Sørsamisk grammatikk. Kárášjohka: Davvi Girji. 
49. MalåLpW = Schlachter, Wolfgang 1958: Wörterbuch des Waldlappendialekts von Malå und Texte zur Ethnographie. Lexica Societatis Fenno-Ugricae XIV. Helsinki: Suomalais-Ugrilainen Seura.

50. Meänkielen sanakirja. http://meankielensanakirja.com (28.2.2021).

51. Morottaja, Petter - Olthuis, Marja-Liisa (tulossa): Inarinsaamen koulukielioppi. Versio 17.11.2020. Sämitigge.

52. Moshnikoff, Satu - Moshnikoff, Jouni - Koponen, Eino - Lehtinen, Miika 2020: Koltansaamen kielioppi. Inari: Sää'mte'ğğ.

53. Moshnikoff, Satu - Moshnikoff, Jouni - Koponen, Eino 2009: Koltansaamen koulukielioppi. Inari: Sää'mte'ğğ.

54. NES = Häkkinen, Kaisa: Nykysuomen etymologinen sanakirja . Verkkoversio.

55. Nickel, Klaus Peter - Sammallahti, Pekka 2011: Nordsamisk grammatikk. Karasjok: Davvi Girji.

56. Nielsen, Konrad 1926: Larebok i lappisk 1. Grammatikk: lydlare, formlare, orddannelseslare og syntaks samt tillegg. Oslo: Brøggers.

57. Ojansuu, Heikki 1922: Itämerensuomalaisten kielten pronominioppia. Turun suomalaisen yliopiston julkaisuja, sarja B, osa 1: 3. Turku.

58. Qvigstad, J. K. 1893: Nordische Lehnwörter im Lappischen. Christiania VidenskabsSelskabs Forhandlingar for 1893 No. 1. Christiania.

59. Rießler, Michael (tulossa): Kildin Saami. - Marianne Bakró-Nagy, Johanna Laakso \& Elena Skribnik (toim.) The Oxford Guide to the Uralic Languages. Oxford: Oxford University Press.

60. Räisänen, Alpo 1996: Suomen kaan-liitteen alkuperä. - Virittäjä 100 (3) s. 375-334.

61. Sammallahti, Pekka 1993: Sámi-suoma-sámi sátnegirji. Ohcejohka: Girjegiisá.

62. Sammallahti, Pekka 1998: The Saami languages. An introduction. Kárášjohka: Davvi Girji.

63. Sammallahti, Pekka 2001: The lndo-European Loanwords in Saami. - Christian Carpelan, Asko Parpola \& Petteri Koskikallio (toim.) Early Contacts between Uralic and Indo-European. Linguistic and Archaeological Considerations s. 397-415. SUST 242. Helsinki: Suomalais-Ugrilainen Seura.

64. Sammallahti, Pekka 2005: Láidehus sámegiela cealkkaoahpa dutkamii. Kárášjohka: Davvi Girji.

65. Sammallahti, Pekka 2007: Gielladutkama terminologiija. Kárášjohka: Davvi Girji.

66. SIKOR $=$ UiT Norjan arktisen yliopiston ja Norjan Saamelaiskäräjien tekstikokoelma, Versio 06.11.2018. http://gtweb.uit.no/korp (28.2.2021).

67. Sjaggo, Ann-Charlotte 2015: Pitesamisk grammatik - en jämförande stude med lulesamiska. Senter for samiske studier, Skriftserie nr. 20. Troms $\varnothing$ : UiT Norges arktiske universitet, Senter for samiske studier.

68. Spiik, Nils Eric 1989: Lulesamisk grammatik. Jokkmokk: Sameskolstyrelsen.

69. SSA = Suomen sanojen alkuperä. Etymologinen sanakirja 1-3. SKST 556. Helsinki: Suomalaisen Kirjallisuuden Seura \& Kotimaisten kielten tutkimuskeskus 1992-2000.

70. SüdLpW = Hasselbrink, Gustav 1981-1985: Südlappisches Wörterbuch I-III. Skrifter utgivna genom Dialekt- och folkminnesarkivet i Uppsala. Ser. C: 4. Uppsala: Dialekt- och folkminnesarkivet.

71. SydSaO = Bergsland, Knut - Magga, Lajla Mattsson 2007: Åarjelsamien-daaroen baakoegarja. Idut.

72. Szabó, László 1967: Kolalappische Volksdichtung (Texte aus den Dialekten in Kildin und Ter). Abhandlungen der Akademie der Wissenschaften in Göttingen. Philologischhistorische Klasse. Dritte Folge, Nr. 68. 
73. Szabó, László 1968: Kolalappische Volksdichtung (aus den Dialekten in Kildin und Ter). Zweiter Teil nebst grammatischen Aufzeichnungen. Abhandlungen der Akademie der Wissenschaften in Göttingen. Philologisch-historische Klasse. Dritte Folge, Nr. 72.

74. Tereškin 2002 = Терешкин, Сергей Николаевич: Йоканьский диалект саамского языка. Väitöskirja. Санкт-Петербург: РПГУ им. А. И. Герцена.

75. Vilkuna, Maria 1996: Suomen lauseopin perusteet. Kotimaisten kielten tutkimuskeskuksen julkaisuja 90. Helsinki: Edita.

76. Wilbur, Joshua 2009: Pite Saami: documenting the language and culture. Endangered Languages Archive. http://hdl.handle.net/2196/00-0000-0000-0003-1170-E (9.3.2021).

77. Wilbur, Joshua 2014: A Grammar of Pite Saami. Studies in Diversity Linguistics 5. Berlin: Language Science Press.

78. Wilbur, Joshua (toim.) 2020: Bidumsáme Báhkogirrje. Internet-tietokanta. http://saami.unifreiburg.de/psdp/pite-lex (3.3.2021).

79. Ylikoski, Jussi 2020: Remarks on the Saami demonstrative pronouns. - Sampsa Holopainen, Juha Kuokkala, Janne Saarikivi \& Susanna Virtanen (toim.), Ёмас сымылу нікве вортурр этппост самын патум. Scripta miscellanea in honorem Ulla-Maija Forsberg s. 398-417. SUST 275. Helsinki: Suomalais-Ugrilainen Seura.

80. Zaikov 1987 = Зайков, П. М.: Бабинский диалект саамского языка: фонологоморфологическое исследование. Петрозаводск: Карелия. 